\title{
Kuwaiti Journalists Attitudes towards the Electronic Media Law as One of the Government Instruments
}

\author{
Prof. Mohammad Al-Qudah* \\ Dr. Fawwaz Al-Ajmi**
}

Dr. Abdelaziz Deehani***

\begin{abstract}
This study aimed to measure the attitudes of Kuwaiti journalists toward the electronic media law. The descriptive approach was used to obtain the preliminary data from the sample of the study, which consisted of 237 individuals. The study concluded that $61.6 \%$ of the respondents read the articles of the new electronic media law, while $69.20 \%$ of the sample did not read the laws of the media of other countries; and $51.90 \%$ of the sample indicated that there were no differences between the laws of other countries and the Kuwaiti electronic law.
\end{abstract}

Results also showed that an average of 2.31 (average degree) indicated that the current electronic law restricts the freedom of journalists in the first place, while an average of 3.93 pointed to its positive effects in reducing sectarian and ethnic strife.

\section{Introduction}

The world is witnessing rapid leaps in quantitative and qualitative development in the fields of communication and its means. On June 25, 2017, the Facebook administration announced that Facebook users were about (2 billion) users, (Facebook Homepage, 2017).

This development was accompanied by problems in authoritarian countries. The researcher Kashakesh argued that "The problem of balance between freedom and power increased in the light of technological developments in the means of communication 
(Kashakesh, 2004), despite the reference in the laws of states with power over the media to freedom of the press and printing." Article (1) of the State of Kuwait law No. 61 stipulated on the freedom of press and printing in accordance to the provisions of this law of 1961. The laws of other countries also refer to this in clear terms. The Jordanian law no. (16) for the year 1976 requires that journalist should be a university graduate or has the secondary school certificate in addition to five years of experience in the profession. This is due to the centralization of the political authority decision and the absence of other authorities. The press was regarded as an instrument of the political authority. Researcher Makkawi refers to this as saying "the developing countries consider media as teachers and builders of the nation and promoters of the government philosophy that calls for the building of a new society, (Makkawi, 2009). There is also an explanation for the control of the press in relation to reliability. AlAbdullah pointed out those relations based on the mutual need between the means of communication and the regime that has become a necessity and binding need (Al-Abdullah, 2010).

There are certainly opinions that show that the relationship between press and authority is based on a number of aspects. Saleh points out to the relationship of rivalries, dependence, complementarity, the commercial relationship, or the mutually beneficial relationship (Saleh, 2005). The researcher goes on to point out to the impossibility of finding a stable relationship between any state and the media, which can be fully applied to one of these patterns. These forms are incompatible with the information revolution or the recent developments in the media. (Saleh, 2005)

Based on these facts, countries differ from each other in the field of freedoms of press and the Gulf countries are a special case in this area.

With regard to the laws and freedom of press, Duffy (2014) pointed out that the assessment of the Gulf States according to the Reporters without Borders and Freedom House as very low. All Gulf States impose restrictions and laws on issuing newspapers and media. According to Hafez (2008), the media system in the Gulf countries is far from being democratic because media laws in the Gulf countries are strict and impose severe restrictions on journalists and media institutions in those countries; these laws, on the other hand, do not 
provide adequate protection for journalists when they address sensitive issues, (Weinberg, 2008 \& Duffy,2014). The Kuwaiti press remains the only Gulf press that is not described as "unfree", due to the Kuwaiti parliamentary regime, as observers believe.

There are three factors that restrict the communication process in the Arab Gulf Countries: penal laws, media laws and cybercrime laws. A number of Gulf States, such as Bahrain in 2002 and Saudi Arabia in 2003 and Kuwait in 2006 amended their laws to include an expanded list of taboos on journalists while others still apply their old laws (Duffy, 2014).

Each GCC country has electronic laws governing the internet and all kinds of technological communication. Some Gulf States, as the UAE and Oman have updated their cybercrime laws by increasing penalties for a number of crimes, such as defamation, spreading rumors and criticizing the government through digital media (Duffy, 2014).

The Law of Electronic Crimes did not appear in the State of Kuwait until 2016 after the government submitted a draft law called the Electronic Media Regulation Law which prohibits the issuance of any electronic newspaper on any platform of internet and social networks without obtaining a license from the Ministry of Information. At the same time, the Cybercrime Law was issued to become a reference for the judgment of crimes committed in the electronic space.

Before the promulgation of these two laws, the Kuwaiti government began to punish those who violated the law on more than one occasion. One of the citizens was jailed for two years because of a tweet which made fun of the Amir of Kuwait, (Duffy, 2014)

Both researchers agree with Siebert that the evolution of the media from the middle of the last century until our modern era was linked to the relationship between media and the political regime according to four major theories of: "authoritarianism - freedom - communism or socialism and finally social responsibility (Seibert, 1956). Seibert added that the classification of media depends on the nature of the dominant political and social regime in the state and its authority over its institutions, media systems and laws, which are often subject to change according to Seibert. Siebert also thinks that the authoritarian information helps the regime control the media, while in the democratic states; the media is free of restrictions on ownership and 
practice. On the other hand, the media loyal to a ruling party defend its interests and improve its image and strengthen its power.

At the end of the last century, Seibert added a new concept to the earlier ones called socio- democratic theory. The essence of this new concept is that the role of the media is to provide the public with the means to express their ideas and to provide the political debate with the information and ideas necessary to ensure the continuity and strengthen the democratic regime in the country".

The researchers believe that this study follows in the theories mentioned above; they will be satisfied with the gate keeper and power in the first place.

\section{Gatekeeper}

The essence of Gate Keeper theory as Schramm points out, "The message goes through many stages and it moves from the source until it reaches the recipient. These stages resemble the chain which consists of several rings" (Schramm, 1960).

This theory starts from the fact that the chains in mass communication are multiple, long and complex before the message reaches the target audience. Also, in this type of series, as the researcher points out, there are certain networks within the systems; the media are networks of systems which can decode, interpret and store information and then put it back in code, a function performed by all communicators "(Rashti, 1975).

One of the ABCs of this theory, as Lewin points out, is that "an individual has the right to decide whether the message he has received will be transmitted or not, and whether that message will reach the second recipient in the same way as it has been initiated, or will it be modified and changed. The researcher goes on to say that the information goes through stages he calls gateways that regulate the quantity and estimate the information that will pass through it, (Lewin, 1951).

Based on this, there are groups of gate keepers entrenched at all stages of the message and have the authority to modify, change or prevent the message from continuity. 
Lewin argues that the essence of understanding the gatekeeper theory is "to understand the influences or factors that govern decisions made by the gatekeeper" (Lewin, 1951)

\section{Power theory}

This theory is based on the theories of Plato and Machiavelli, namely, that authority is represented by the ruler who bears responsibility because the people are not worthy of bearing responsibility. The powers of the authority are to monopolize and monitor the work permits and control them, and not to infringe on the authority and its symbols who grant journalists the privilege of working in the press, which requires commitment to the authority.

\section{$\underline{\text { Related Studies }}$}

Quteifan, Lana, 2013, conducted a study, entitled "The role of law to guarantee the right to information in media coverage" (Quteifan, 2013).The study came out with several results, the most prominent of which is that "journalists know that they have the right to access knowledge". In the first place came the item "A Jordanian citizen was aware of the law" with a mean of 2.97. In the second place was the item " the Jordanian journalist was informed of the right to information law" with a mean of 2.84.The third place was occupied by the item, "I am knowledgeable about the laws of the right to information in other countries" with a mean of 2.75 , and about the role of law in promoting the principle of free access to information, "The law meets the needs of Jordanian journalists to obtain information" With a mean of 2.73. In the second place, came the item "The law which supports the right to access information enhances my information freedom in Jordan" with a mean of 2.73. In the third place, "the Law was the appropriate way to obtain information" with a mean of 2.62. The study also indicated that "Media freedoms witnessed a marked decline" with a mean of 2.91, and the "Media legislation is a restriction on media freedom" with a mean of 2.84 .

)Shammari, Youssef, 2013) conducted a study on "The relationship between media and governments' "soft containment" and independence: field study in the State of Kuwait. Results of the study showed that there are many parties that exert pressure on the media. The item of the Kuwaiti governments and their various institutions exert pressure came in the first rank with a mean of (3.35); and the 
departments of media organizations ranked second with a mean of (3.09); the religious and sectarian leaders of Kuwait ranked third with a mean of 2.89; the Kuwaiti National Assembly and its members ranked fourth with a mean of 2.81; and the Kuwaiti tribes came at the fifth rank with a mean of (2.63). The results of the study showed that the nature of the relationship between the governments and the media is varied. In the first place, there was a fluctuation between the previous patterns with a mean of (3.69). In the second place there was a relationship based on the soft containment of the media with a mean of 3.46. In The third place came the item "based on independence and mutual respect with a mean of (2.82). The results also indicated that the governmental methods aimed at the smooth containment of the media were medium for all items. In the first place came the item "some governments provide financial aids and gifts to some media officials to win their favor" with a mean of (3.84). In the second place came "Governments discriminate between media officials by providing them with news and information" with a mean of (3.32). In the third place was the item "governments discriminate among the Media men by inviting some of them to meetings "with a mean of (3.15). The results of the study also showed that some Kuwaiti journalists enjoy high independence in their work with a mean of (3.86). In the second place, the item of "journalists of electronic media were highly independent with a mean of (3.58), while the item "journalists in the newspapers enjoy high independence was ranked third with a mean of $(3.41($

Al-Enezi (2011) conducted a study entitled "The impact of the publications law on the Kuwaiti Press", the study concluded that in reality of press work in the State of Kuwait the item "The auditor intervenes in the written article submitted according to his concept of the press work in the first rank with a mean of (3.93), and a standard deviations standard deviations of 0.76 . In the second place "the source controls the type of material published and the subjects covered by the journalist came with a mean of 3.92 and a standard deviation of 0.70 . In the third place came the item "The auditor intervenes in the editorial according to his experience, not according to the accepted press bases and conventions, with a mean of (3.86) and with a standard deviation of 0.66. In the fourth place was the item "the official intervenes centrally in the work of the journalist or editor in the preparation of the 
press article with a mean of (3.83), and a standard deviation of 0.63. In the eleventh rank came the item "The Board of Directors strictly intervenes in determining the agenda for the work of journalists with an average of 3.15 and with a standard deviation of 0.84 . Results also show that there is a convergence in the values of means in the views of the study sample members about the reality of press work in the State of Kuwait, where all significance levels were less than (0.05) for all items. In general, the reality of press work in the State of Kuwait from the point of view of the study sample was average (Al-Enezi, 2011, 119). The study results in all items were high with a mean of (4.10) and a standard deviation of 0.62. The item "The Publication Law guarantees the ethics of the media work and takes care of the search for truth and objectivity away from favoritism and to put the entire picture without hiding or neglecting part thereof" was ranked first with a mean of (4.53), while the item "The Publications Law in the State of Kuwait impedes the field of investigative journalism and thus the role of the press in detecting irregularities and official abuses in all sectors of the country" came in the second place with a mean of 4.52. In the third place came the item "I have knowledge of the provisions of the law of publications in the State of Kuwait" with an average of 4.43. It is noted that other items are high, for example the financial guarantee paid by the newspaper to the state is a form of taxes with an mean of 4.36.The articles of the Publication Law are subject for evaluation and renewal in the light of the spread of newspapers in the State of Kuwait with a mean of 4.33 and the item "The publication law allows disclosure of any documents, or secret meetings" came with a mean of (3.94). "Kuwait's Publications and Technical Works Law limits the powers of journalist" came with (3.91), the item "The news is transmitted as it is without concealment or neglecting part of it," received a mean of 3.85; and the item "The publications law of the State of Kuwait impedes the press from exercising its role as a fourth authority to be added for all other authorities " came with a mean of 3.83. Results of the study proved that" there is a significant statistical relationship at $\alpha=.05$ between the law of publications in Kuwait and the expansion of press institutions as well as the work of journalists in Kuwait. 
Al Ajmi, did a research entitled "The new press law: Kuwaiti journalists and newspapers owners' knowledge and attitude." (Ajmi, 2011).The study focused on

The impact of the new Kuwaiti Publication Law issued in 2006 on the Kuwaiti press using the theory of setting the agenda. The study showed that Kuwaiti journalists from various Kuwaiti newspapers were well aware of the Kuwaiti Publications Law. The study also concluded that the new Kuwaiti Publications Law reduced the Kuwaiti government's authority over newspapers, though it is there, as the study participants believe. The study found that Kuwaiti journalists do not consider the level of freedom of press in Kuwait high enough, and that the government's role in the daily newspapers has become more complicated with the emergence of the new law (Ajami, 2011). The researcher states that the Kuwaiti journalists believe that the new publications law has greatly affected the process of managing daily newspapers in Kuwait. The study indicates that $51 \%$ of the sample involved is sufficiently familiar with the new Kuwaiti Publications Law. The new law prohibits criticizing God and the Amir and forbids publishing what would have a negative impact on Kuwait's relations with other countries. $77 \%$ of the respondents said the government banned some newspapers from publishing sensitive topics while allowing other newspapers, and $72 \%$ said the new law had increased competitiveness among local newspapers. According to the study, $71.6 \%$ of respondents believe that the government gives itself greater powers more than what is prescribed by law. $65.5 \%$ of the respondents indicated that the new law reinforced the diversity of subjects presented in the Kuwaiti newspapers, and $59.7 \%$ believe that there is high freedom of press in Kuwait, (Ajami, 2011.(

(Kashakesh, 2004) conducted a study entitled " crisis of freedom of press in the Jordanian legislation; a study in the legal aspect of the Jordanian press represented in the laws of publishing as laws designed in its entirety to regulate the relationship between the state and the press on the constitutional and legal grounds, (Kashakesh, 2004.2 ). The study found a large number of results as the study deals with the publishing laws in the Jordanian legislation in the field of press and publication. The most prominent results of the study showed that the two laws of publications for the years 1967 and 1973 have taken unfortunate trend towards restricting the freedom of the press, 
especially in texts related to licensing, and the prohibited material from publishing, besides crimes of publications and administrative sanctions (Kashakesh, 2004, 18). This is what is noted in the recent laws of some countries, such as the Electronic Media Act of Kuwait in 2016. The study also concluded that the 1973 law was a sword on journalists' necks, as it denies them the right to litigation or not to respond to the license or revoke the license (Kashakesh, 2004, 18). The study concluded that the law of 1993, as some critics of the articles of this law, especially in the field of licensing of newspapers or the end of the license is balanced and stable in many similar legislations. These laws have contributed in giving Jordan credibility at the international level in issues of public freedoms, (Kashakesh, 2004, 19).

\section{Problem of the Study}

The developing countries are witnessing a strong struggle between authorities on the one hand, and the media on the other. This is because authorities in the third world countries attempt to control the media by all means, including the enactment of legislations that allow authorities to control the media through legislations that allow, or block, including legislations that govern the media laws in those countries, which in one way or another is reflected on press and institutional work in a different way. Both researchers believe that the issuance of the Kuwaiti Electronic Media Law has raised a wide debate about its articles and its effects on a number of aspects, such as the freedom of media work in media institutions and websites. The study problem is limited in monitoring and measuring the extent of approval or disapproval of this law, and its articles by journalists in the Kuwaiti media institutions.

\section{Importance of the Study}

The importance of this study lies in the attempt to enrich the studies and researches conducted on publication laws in the State of Kuwait, on the one hand, and the Arab library on the other. The researchers believe that the study of any scientific phenomenon is a basis for understanding it as an old and modern phenomenon, i.e. laws governing media work. The importance of this study also stems from the investigation of an important segment of the press body, namely, the segment of journalists in the Kuwaiti press institutions, a segment 
whose role in the Kuwaiti press work cannot be overlooked. Therefore, it can be said that this study is one of the few studies - if not the first conducted on employees of Kuwaiti press institutions.

Furthermore, this study examines the attitudes of Kuwaiti journalists towards the new electronic media law, and defines the relationship between this law and press work in Kuwait, besides showing its negative or positive effects on the work of journalism and media institutions.

\section{This study is also important because:}

The study recommendations and suggestions will benefit the specialized institutions and communicators in addressing problems faced by journalists and media institutions

- Provide the National Library and Arab libraries with researches and studies on this important aspect in the press work .

- To identify the views of journalists towards the legislative laws related to their press work at the media institutions.

\section{The Study Questions and Hypotheses}

This study intended to answer the following questions:

Question 1: Did you learn about the Kuwaiti new electronic media law?

Question 2: Have you read the electronic media laws of other countries?

Question 3: Did you find fundamental differences between the Kuwaiti electronic media law and the media laws that you have read in other countries?

Question 4: In your point of view, do you think that Kuwaiti media institutions will be obliged to apply the new law to electronic media?

Question 5: What are the consequences of the electronic media law on the Kuwaiti press institutions?

Question 6: Will the new electronic media law affect the State of Kuwait positively? 
Question 7: What is the alternative to the laws of electronic media, publications and publishing?

Question 8: To what extent do you degree with the articles of the new media law?

\section{Hypotheses and Relations}

Hypothesis One: There are significant statistical differences at $\alpha=.05$ between sex and the impact of the media law on the Kuwaiti press institutions in various fields.

Hypothesis two: There are significant statistical differences at $\alpha=.05$ between sex and the impact of the new electronic media law positively on the State of Kuwait in various fields.

Hypothesis Three: There are significant statistical differences at $\alpha=.05$ between sex and the articles of the new media law.

Hypothesis four: There are significant statistical differences at $\alpha=.05$ between age and the impact of the media law on the Kuwaiti press institutions in various fields.

Hypothesis five: There are significant statistical differences at $\alpha=.05$ between age and the impact of the new electronic media law positively on the State

of Kuwait in various fields

Hypothesis six: There are significant statistical differences at $\alpha=.05$ between age and the articles of the new media law.

Hypothesis seven: There are significant statistical differences at $\alpha=.05$ between the education level and the impact of the media law on Kuwaiti press institutions in various fields

Hypothesis Eight: There are significant statistical differences at $\alpha=.05$ between the education level and the positive impact of the new electronic media law on the State of Kuwait in various fields

Hypothesis nine: There are significant statistical differences at $\alpha=.05$ between the education level and the articles of the new media law.

Hypothesis ten: There are significant statistical differences at $\alpha=.05$ between the monthly income and the implications of the media law on the Kuwaiti press institutions in various fields. 


\section{$\underline{\text { Relationships }}$}

1. What is the relationship between the monthly income and the alternative to the laws of electronic media, publications and publishing?

2. What is the relationship between the educational level and the alternative to the laws of electronic media, publications and publishing?

3. The relationship between the items:

1- Have you read the various articles of the Kuwaiti new electronic media law?

2- Have you read the electronic media laws of other countries?

3- Are there fundamental differences between the electronic media law and the media laws that you have read in other countries?

\section{Type of Study and Methodology}

This study is subsumed under the analytical descriptive studies, which deals with the current facts about the phenomenon studied: (The Kuwaiti journalists' attitudes towards the electronic media law). This methodology is considered a systematic scientific effort which aims at obtaining information and data about one or more phenomena to form a data base that helps to diagnose and interpret phenomena so as to provide an objective picture of the research". (Abdel Hamid, 1993)

\section{Limitations of the Study}

The study is limited by time and place:

Time limits: (February - April 2018)

Place Limits: - Kuwaiti press institutions (daily newspapers - news agency - Kuwait Radio and Television) - Kuwait.

1.This study was limited to:

2. The study instrument represented by the questionnaire that was prepared to achieve the objectives of the study and answer its questions.

3) Results to be obtained. 


\section{The Study Instruments}

The study was based on a questionnaire as a research instrument distributed to the Kuwaiti daily newspapers, Kuwait News Agency, Radio and Television to closely monitor the Kuwaiti journalists' attitudes towards the electronic media law.

\section{Validity and Reliability of the Study Instrument}

Validity of the instrument was confirmed by presenting it to a group of arbitrators who are specialized in media, namely: Dr. Abdul Karim Al Zayani, University of Bahrain, Dr. Mohammed Al-Sallous, Yarmouk University.

Face validity of the test refers to the appropriateness of the questionnaire in terms of vocabulary, wording, clarity and validity.

A pre-test of the questionnaire was carried out on a group of nonmembers of the study population, (25 individuals) were involved to identify errors in the questionnaire, as incomprehensible or unclear terms to modify and reformulate them as needed.

\section{The Study Population and Sample}

Journalists working in Kuwait's daily newspapers (Al-Siyassa- AlRai-Alqabas-Al-Nahar-Al-Jarida-Al-Anbaa) were selected as the study population. The study population was 502 journalists (according to the records of the Kuwait Journalists Association), and 270 were selected for the application. The questionnaire was distributed to all daily newspapers, the news agency, Kuwait Radio and Kuwait TV according to the intentional sample system at a rate of 30 units for each institution. 260 questionnaires were received back. After checking, it was found that 237 were good for statistical analysis, which is a very acceptable percentage.

\section{Methods of Data Analysis}

The SPSS program was used on its descriptive and analytical levels as follows:

A) At the descriptive level: Calculation of frequencies and percentages- calculation of means and standard deviations and simple complex boundaries.

B) At the analytical level: T-test \& Chi square $X 2$ to measure the level of significance between variables. 
- Coefficient of compatibility to measure the strength of the relationship between variables; one -way a nova.

\section{Sample of the Study}

The sample of the study consisted of (237) Kuwaiti journalists who were intentionally selected. Table (1) shows the distribution of the sample members according to personal and occupational variables.

Table (1): Shows distribution of the sample according to the personal variables

\begin{tabular}{|c|c|c|c|}
\hline Variable & Category & Number & Percentage $\%$ \\
\hline \multirow{3}{*}{ Sex } & Female & 183 & 77.2 \\
\hline & Male & 38 & 16.0 \\
\hline & Total & 221 & 93.2 \\
\hline \multirow{6}{*}{ Age } & 25 years \& under & 13 & 5.5 \\
\hline & $26-30$ & 37 & 15.6 \\
\hline & $31-35$ & 70 & 29.5 \\
\hline & $36-40$ & 36 & 15.2 \\
\hline & 41 and over & 71 & 30.0 \\
\hline & Total & 227 & 95.8 \\
\hline \multirow{5}{*}{ Educational Level } & Less than SECONDARY & 25 & 10.5 \\
\hline & Diploma & 16 & 6.8 \\
\hline & Bachelor & 162 & 68.4 \\
\hline & Master/ Ph.D. & 19 & 8.0 \\
\hline & Total & 222 & 93.7 \\
\hline \multirow{9}{*}{ Profession } & Journalist & 121 & 51.05 \\
\hline & Editor & 78 & 32.91 \\
\hline & Legal Journalist & 3 & 1.26 \\
\hline & Announcer & 16 & 6.75 \\
\hline & Program maker & 8 & 3.37 \\
\hline & Journal producer & 6 & 2.53 \\
\hline & Sports journal & 3 & 1.26 \\
\hline & Economic journal & 2 & 0.84 \\
\hline & Total & 237 & 100 \\
\hline \multirow{6}{*}{ Monthly Income } & 1000 or less & 128 & 54.0 \\
\hline & $1001-2000$ & 48 & 20.3 \\
\hline & $2001-3000$ & 7 & 3.0 \\
\hline & $3001-4000$ & 3 & 1.3 \\
\hline & $4001 \&$ over & 2 & 0.8 \\
\hline & Total & 188 & 79.3 \\
\hline
\end{tabular}

Table (1) above shows the following:

* With regard to the sex variable, it appears that females are the most frequent (183) with a percentage of $(77.2 \%)$, while males are the least frequent (38) with a percentage of $(16.0 \%$.).

As for the age variable, those aged 41 and over are the most frequent $(71)$ with a percentage of $(30.0 \%)$ while those aged 25 
and under are the least frequent (13) with a percentage of $(5.5 \%)$.

* Regarding the educational level variable, it was found that those who had a bachelor degree were the most frequent (162) with a percentage of $(68.4 \%)$, while those who hold a diploma were the lowest frequent (16) with a percentage of $(6.8 \%$ This is due to the low illiteracy rate in Kuwait, which is $3 \%$.

* As for the profession variable, it appears that the profession of "journalist" came in the first place (121) with a percentage of $(51.05 \%)$, while the profession of a press editor ranked second (78) with a percentage of $(32.91 \%)$.

* As for the monthly income variable those with a monthly income of "1000 or less" are the most frequent (128) with a percentage of (54.0\%) while those with a monthly income of 4001 or more are the lowest frequent (2). The reason for this is that the press work in Kuwait is a secondary work for a large percentage of journalists and media workers in Kuwait because the financial returns are low.

\section{Presentation of Result}

This section contains the results of the study which aimed at identifying the attitudes of Kuwaiti journalists towards the electronic media law. The results will be presented based on the questions and hypotheses of the study.

First: Questions related to the Electronic Media Law

Table (2): shows frequencies and percentages of questions related to the electronic media law

\begin{tabular}{|l|l|l|l|}
\hline Questions & Category & Frequency & Percentage\% \\
\hline \hline \multirow{2}{*}{$\begin{array}{l}\text { Did you learn about the Kuwaiti new electronic } \\
\text { media law? }\end{array}$} & Yes & 146 & 61.60 \\
\cline { 2 - 4 } & No & 90 & 37.97 \\
\cline { 2 - 4 } & Total & 236 & 99.58 \\
\hline \hline \multirow{2}{*}{$\begin{array}{l}\text { Have you read the electronic media laws of other } \\
\text { countries? }\end{array}$} & Yes & 70 & 29.54 \\
\cline { 2 - 4 } & No & 164 & 69.20 \\
\cline { 2 - 4 } & Total & 234 & 98.73 \\
\hline \hline \multirow{2}{*}{$\begin{array}{l}\text { Did you find fundamental differences between } \\
\text { the Kuwaiti electronic media law and the media }\end{array}$} & Yes & 29 & 12.24 \\
\cline { 2 - 4 } laws that you have read in other countries? & No & 123 & 51.90 \\
\cline { 2 - 4 } & Total & 152 & 64.14 \\
\hline \hline \multirow{2}{*}{$\begin{array}{l}\text { In your point of view, do you think that Kuwaiti } \\
\text { media institutions will be obliged to apply the } \\
\text { new law to electronic media? }\end{array}$} & Yes & 165 & 69.62 \\
\cline { 2 - 4 } & No & 63 & 26.58 \\
\cline { 2 - 4 } & Total & $\mathbf{2 2 8}$ & $\mathbf{9 6 . 2 0}$ \\
\hline
\end{tabular}

Table (2) above shows the following:

First Question: Did you learn about the Kuwaiti new electronic media law?

The results showed that those who answered "Yes" were the most frequent they were (146) with a percentage of (61.60\%). This result is 
consistent with the studies of Al-Enezi, 2011 and Quteifan, 2013, while those who answered "No" were the least frequent (90) with a percentage of $(37.97 \%)$. We find that there is a significant lack of interest in reading the law and its articles by a good number of Kuwaiti journalists. This may reflect negatively on their performance and their response to the law and commitment to it. Hence, adequate awareness campaigns of the law and its articles are required by their officials.

Second Question: Have you read the electronic media laws of other countries?

The results showed that those who responded "no" were the most frequent (164) with a percentage of $(69.20 \%)$; while those who answered "Yes" are the least frequent (70) with a percentage of (29.54\%). The results of this question may justify such an outcome. A journalist who is not interested in reading his own laws will not be interested in reading the laws outside his country.

Third Question: Did you find fundamental differences between the Kuwaiti electronic media law and the media laws that you have read in other countries?

The results showed that those who answered "No" were the most frequent, they were (123) with a percentage of (51.90\%), while those who answered "Yes" were the lowest frequent, (29) with a percentage of $(12.24 \%)$. This result agrees with questions $1 \& 2$

Fourth Question: In your point of view, do you think that Kuwaiti media institutions will be obliged to apply the new law to electronic media?

The results showed that those who responded "yes" were the most frequent, they were (165) with a percentage of $(69.62 \%)$; while those who answered "no" were the least frequent about (63) with a percentage of (26.58\%). As long as it was a government law, no doubt that everyone will abide by its articles to avoid its violation and any penalties.

Fifth Question: What are the consequences of the electronic media law on the Kuwaiti press institutions?

In order to answer this question, the means and standard deviations of each field item were calculated "the consequences of the Electronic 
Media Law on Kuwaiti Press Institutions". The researcher employed the triple - level Likert scale to measure the opinions of the sample of the study, as follows:

Many was given (3), sometimes (2), and no (1) by putting $(\sqrt{ })$ before the answer that reflects their degree of approval. The following classification was also used to judge the means as follows:

-Less than 1.66: Low.

-From 1.67 to 2.33: Mediocre

-from 2.34 and above: High

- Table (3) shows this.

Table (3): shows the means and the standard deviations of the field items "The consequences of the Electronic Media Law on the Kuwaiti Press Institutions" and the field as a whole $(n=237)($

\begin{tabular}{|c|c|c|c|c|c|}
\hline No. & Item & Mean & $\begin{array}{l}\text { Std. } \\
\text { Deviations }\end{array}$ & Rank & Degree \\
\hline 1 & Limited the independence of journalists & 2.31 & 0.67 & 1 & mediocre \\
\hline 2 & Limited personal freedoms & 2.21 & 0.73 & 2 & mediocre \\
\hline 3 & Limited press creativity & 2.05 & 0.77 & 4 & mediocre \\
\hline 4 & $\begin{array}{l}\text { Found frightening for journalists to } \\
\text { practice freely }\end{array}$ & 2.11 & 0.76 & 3 & mediocre \\
\hline 5 & $\begin{array}{l}\text { Damaged the Kuwaiti press reputation } \\
\text { at the global level }\end{array}$ & 1.97 & 0.80 & 6 & mediocre \\
\hline 6 & $\begin{array}{l}\text { Draw back press to weak levels of } \\
\text { global transparency }\end{array}$ & 2.04 & 0.77 & 5 & mediocre \\
\hline \multicolumn{2}{|c|}{$\begin{array}{l}\text { Consequences of the electronic media law on } \\
\text { Kuwaiti press institutions as a whole }\end{array}$} & 2.11 & 0.56 & - & mediocre \\
\hline
\end{tabular}

Table (3): shows that means ranged between 1.97 and 2.31. Item (1), which states "limited the independence of journalists" ranked first with a mean of (2.31) and mediocre, followed by item (2) Which stipulates that " limited personal freedom" with a mean of (2.21) and mediocre. This result is consistent with (Al-Enezi, 2011, AlShammari, 2013, \& Quteifan, 2013) studies. In the last rank, was item (5) "damaged the Kuwaiti press reputation at the global level" with a mean of (1.97), and mediocre.

The mean of the field "the consequences of the electronic media law on the Kuwaiti press institutions" as a whole was (2.11), and 
mediocre. Both researchers believe that this is logical, although media laws in particular have implications for the independence of journalists on the one hand, and the press institutions on the other; The Kuwaiti society is a democratic one that places great importance on independence and freedoms; and the Kuwaiti press is known to have a high level of freedom compared with other Gulf and Arab countries.

Sixth Question: Will the new electronic media law affect the State of Kuwait positively?

To answer this question, means and standard deviations were calculated for each of the items of the "positive aspects of effect" and the field as a whole. The researchers used a five-dimensional Likert scale to measure the opinions of the study sample members as follows: strongly agree was given (5), agree (4) neutral (3), disagree (2), strongly disagree (1), by putting $(\sqrt{ })$ before the answer that reflects their degree of approval. The following classification is also based on the following means:

-Less than 2.33: Low.

-From 2.33 to 3.66: Mediocre

-from 3.67 - 5.00: High

- Table (4) shows this.

Table (4): shows means and standard deviations of the field "positive aspects of effect" and the field as a whole $(n=237)$

\begin{tabular}{|l|l|l|l|l|l|}
\hline No. & Item & Mean & $\begin{array}{l}\text { Std. } \\
\text { Deviations }\end{array}$ & Rank & Degree \\
\hline 1 & Protect religious beliefs of people & 3.76 & 1.09 & 2 & High \\
\hline 2 & Reduce sectarian and ethnic strife & 3.93 & 1.10 & 1 & High \\
\hline 3 & strengthen national unity & 3.71 & 1.10 & 3 & High \\
\hline \multicolumn{2}{l}{ positive aspects of effect } & $\mathbf{3 . 8 0}$ & $\mathbf{0 . 9 5}$ & - & High \\
\hline
\end{tabular}

Table (4): shows that means ranged between (3.71-3.93). where item (2), which states that "the reduction of sectarian and racial strife" is ranked first with a mean of (3.93) and a high score, followed by item (1) Which states that " protection of religious beliefs of people" with a mean of (3.76) and high; and the last rank, item (3), which states "an important factor in the strengthening of national unity" with a mean of 3.71 and high; and the mean of the whole field " positive aspects of effect" was (3.80) and high. Both researchers argued that this is connected with what is raised by some media outlets of messages 
considered by the government institutions to provoke sectarian and religious strife. This is one of the motives that made the Kuwaiti government represented by the Ministry of Information keen on finding such a law as a result of conflicts and wars waging in the surrounding region, which requires strengthening national unity within Kuwait by renouncing racism and all forms of strife.

Seventh Question: What is the alternative to the laws of electronic media, publications and publishing?

Table (5): shows frequencies and percentages of questions related to the alternative to the laws of electronic media, publications and publishing

\begin{tabular}{|l|l|l|l|}
\hline Questions & Category & Frequency & Percentage \% \\
\hline \multirow{3}{*}{ Media code of honor } & Yes & 125 & 52.74 \\
\cline { 2 - 4 } & No & 90 & 37.97 \\
\cline { 2 - 4 } & Total & 215 & 90.72 \\
\hline \hline \multirow{2}{*}{$\begin{array}{l}\text { Code of occupational ethics for all media } \\
\text { institutions }\end{array}$} & Yes & 156 & 65.82 \\
\cline { 2 - 4 } & No & 58 & 24.47 \\
\cline { 2 - 4 } & Total & 214 & 90.30 \\
\hline
\end{tabular}

Table (5) shows the following:

As for the question of Media code of honor, those who answered "yes" were the most frequent (125) with a percentage of $(52.74 \%)$, while those who answered "no" were the lowest frequent (90) and a percentage of $(37.97 \%)$. It is very unfortunate that most third world countries do not adopt media codes of honor, but rely on media laws governing the media process from the point of view of these governmental institutions, in line with the guidance of the media institutions and government policies of these countries.

The question, code of occupational ethics for all media institutions shows that those who responded "yes" are the most frequent, they were (156) with a percentage of $(65.82 \%)$; while those who answered "no" are the lowest frequent, the were (58) and the percentage was $(24.47 \%)$. This indicates that there is an urgent need for an ethical code in the media institutions that serves as a guide for the media men in their work, and prevents them from committing irregularities that are not commensurate with the ethics of the profession.

Eighth Question: Degree of agreement with the new media law articles 
To answer this question, means and standard deviations were calculated for each of the items of the "degree of agreement with the new media law articles" and the field as a whole. The researchers used a five-dimensional Likert scale to measure the opinions of the study sample members as follows: strongly agree was given (5), agree (4) neutral (3), disagree (2), strongly disagree (1), by putting $(\sqrt{ })$ before the answer that reflects their degree of approval. The following classification is also based on the following means:

-Less than 2.33: Low.

-From 2.33 to 3.66: Mediocre

-from 3.67 - 5.00: High

Table (6): shows means and standard deviations for all items which measure the degree of agreement with the new media law articles. $(\mathrm{N}=\mathbf{2 3 7})$

\begin{tabular}{|c|c|c|c|c|c|}
\hline No & Item & Mean & $\begin{array}{l}\text { St. } \\
\text { Deviations }\end{array}$ & Rank & Degree \\
\hline 1 & $\begin{array}{l}\text { Electronic media is one of the components of the } \\
\text { media system in the State and its freedom of use } \\
\text { is guaranteed to all in accordance with the } \\
\text { provisions of this law. And to pre-catch up on } \\
\text { what is being traded content through sites and } \\
\text { media. }\end{array}$ & 3.89 & 1.03 & 4 & High \\
\hline 2 & $\begin{array}{l}\text { The State shall take care of the electronic media } \\
\text { sites and means subject to the provisions of this } \\
\text { law and its employees and provide the necessary } \\
\text { facilities to keep abreast of the steady } \\
\text { technological development of the electronic media } \\
\text { in accordance with the executive regulations of } \\
\text { this law }\end{array}$ & 3.64 & 1.09 & 13 & Mediocre \\
\hline 3 & $\begin{array}{l}\text { The website of the Ministry shall publish a special } \\
\text { record of the licensed websites in accordance with } \\
\text { the provisions of this law }\end{array}$ & 3.78 & 1.08 & 5 & High \\
\hline 4 & $\begin{array}{l}\text { The executive regulations of this law shall } \\
\text { regulate opinion polls conducted by licensed } \\
\text { electronic media means and sites. }\end{array}$ & 3.65 & 1.11 & 12 & Mediocre \\
\hline 5 & $\begin{array}{l}\text { The provisions of this law shall not apply to the } \\
\text { scope, location, means or personal electronic } \\
\text { account of which the user is not specialized }\end{array}$ & 3.71 & 1.15 & 8 & High \\
\hline 6 & $\begin{array}{l}\text { To specify the name of the electronic media site } \\
\text { or medium, provided that it is not contrary to } \\
\text { public order or public morals or identical or } \\
\text { similar to the name of another site }\end{array}$ & 4.00 & 0.99 & 2 & High \\
\hline 7 & $\begin{array}{l}\text { To have a specific location for the licensed } \\
\text { activity. }\end{array}$ & 3.72 & 1.04 & 6 & High \\
\hline
\end{tabular}




\begin{tabular}{|c|c|c|c|c|c|}
\hline 8 & $\begin{array}{l}\text { For newspapers and satellite television channels - } \\
\text { licensed by the Ministry - wishing to establish a } \\
\text { website or an electronic media means to provide a } \\
\text { copy of the license issued with the request. }\end{array}$ & 3.95 & 0.95 & 3 & High \\
\hline 9 & $\begin{array}{l}\text { The responsible director shall be: A Kuwaiti } \\
\text { citizen, not less than ( } 21) \text { years old, be fully } \\
\text { qualified and have at least a high school certificate } \\
\text { or equivalent }\end{array}$ & 3.30 & 1.22 & 21 & Mediocre \\
\hline 10 & $\begin{array}{l}\text { The responsible director shall be required to: } \\
\text { Have a good reputation and not have been } \\
\text { sentenced to a felony or a crime against honor or } \\
\text { trust unless he has been rehabilitated }\end{array}$ & 4.27 & 0.92 & 1 & High \\
\hline 11 & $\begin{array}{l}\text { He shall not be a manager of another licensed } \\
\text { website or media outlet }\end{array}$ & 3.72 & 1.07 & 6 & High \\
\hline 12 & $\begin{array}{l}\text { The Minister shall issue a decision regarding the } \\
\text { application for the license within thirty days from } \\
\text { the date of submission of the application in } \\
\text { compliance with the conditions prescribed by law. } \\
\text { If this period elapses without the issuance of the } \\
\text { decision, the application shall be considered } \\
\text { rejected and the concerned parties may appeal the } \\
\text { decision of refusal to the Minister within } 60 \text { days } \\
\text { from the date of the rejection if the duration } \\
\text { elapsed without a decision, the appeal shall be } \\
\text { deemed rejected. }\end{array}$ & 3.53 & 1.06 & 19 & Mediocre \\
\hline 13 & $\begin{array}{l}\text { The applicant for the license to the site or } \\
\text { electronic media must submit within sixty days } \\
\text { from the date of notification of approval of the } \\
\text { license to the treasury of the Ministry a financial } \\
\text { guarantee of five hundred dinars. }\end{array}$ & 3.59 & 1.04 & 18 & Mediocre \\
\hline 14 & $\begin{array}{l}\text { Without prejudice to any other legislative } \\
\text { provision, the license shall be revoked in the } \\
\text { following cases: If the licensee is a legal person } \\
\text { and his legal personality has expired for any of the } \\
\text { reasons prescribed by law. }\end{array}$ & 3.69 & 0.97 & 9 & High \\
\hline 15 & $\begin{array}{l}\text { Without prejudice to any other legislative } \\
\text { provision, the license shall be revoked in the } \\
\text { following cases: } 1 \text {. If the licensee is a legal person } \\
\text { and his legal personality has expired for any } \\
\text { reason determined by law }\end{array}$ & 3.62 & 0.99 & 15 & High \\
\hline 16 & $\begin{array}{l}\text { Without prejudice to any other legislative } \\
\text { provision, the license shall be revoked in the } \\
\text { following cases: } \\
\text { 2. If the position of the responsible manager is } \\
\text { absent or the designated director loses one of the } \\
\text { conditions necessary for it, and the licensee does } \\
\text { not appoint an alternative to meet the prescribed } \\
\text { conditions within the specified period }\end{array}$ & 3.39 & 1.14 & 20 & Mediocre \\
\hline 17 & $\begin{array}{l}\text { Without prejudice to any other legislative } \\
\text { provision, the license shall be revoked in the } \\
\text { following cases: } 3 \text {. If the licensee rents the license }\end{array}$ & 3.66 & 1.09 & 10 & Mediocre \\
\hline
\end{tabular}




\begin{tabular}{|l|l|l|l|l|l|}
\hline 18 & $\begin{array}{l}\text { Without prejudice to any other legislative } \\
\text { provision, the license shall be revoked in the } \\
\text { following cases: } 4 \text {. If the licensee sells the license } \\
\text { or waives it without the approval of the Ministry. }\end{array}$ & 3.60 & 1.08 & 17 & Mediocre \\
\hline 19 & $\begin{array}{l}\text { Without prejudice to any other legislative } \\
\text { provision, the license shall be revoked in the } \\
\text { following cases: 5. If the licensee does not carry } \\
\text { out the licensed activity within the period } \\
\text { stipulated in Article (13) of this law }\end{array}$ & 3.63 & 1.04 & 14 & Mediocre \\
\hline 20 & $\begin{array}{l}\text { Without prejudice to any other legislative } \\
\text { provision, the license shall be revoked in the } \\
\text { following cases: 6. If the license term ends } \\
\text { without requesting renewal within six months } \\
\text { from the date of its termination }\end{array}$ & 3.61 & 1.05 & 16 & Mediocre \\
\hline 21 & $\begin{array}{l}\text { Without prejudice to any other legislative } \\
\text { provision, the license shall be revoked in the } \\
\text { following cases: } 7 . \text { If the licensee dies and has no } \\
\text { legal heirs or if the heirs did not transfer the } \\
\text { license within the specified period }\end{array}$ & 3.66 & 1.09 & 10 & Mediocre \\
\hline $\begin{array}{l}\text { Degree of agreement with the new media law articles, } \\
\text { as a whole }\end{array}$ & $\mathbf{0 . 5 9}$ & $\mathbf{0 . 5 9}$ & - & High \\
\hline
\end{tabular}

Table (6) above shows that means of the "degree of agreement with the new media law" ranged from 3.30-4.27, the top of which is item 10, which states: "The responsible director shall be required to have good reputation He has never been convicted of a felony or offense against honor or trust unless he has been rehabilitated "with a mean of 4.27 and a high degree. Followed by item (6), which states: "To specify the name of the electronic media site or medium, provided that it is not contrary to public order or public morals or identical or similar to the name of another site" with a mean of 4 and a high grade.in the last place came item (9) Which stipulates that: " The responsible director shall be: A Kuwaiti citizen, not less than (21) years old, be fully qualified and have at least a high school certificate or equivalent " with a mean of (3.30) and a mediocre degree. The mean of "degree of agreement with the new media law" as a whole was (3.70) and high degree. The researchers argue that the reason for this may be due to the reasonable articles of the law and their compatibility with the media market of Kuwait.

\section{Hypotheses and Relationships}

Hypothesis One: There are significant of statistical differences at $\alpha=.05$ between sex and the impact of the media law on the Kuwaiti press institutions in various fields. 
In order to test this hypothesis, means and standard deviations of the impacts of the media law on the Kuwaiti press institutions in various fields and their degree according to the sex variable. The Independent Samples and T Test were used to detect the differences in the effects of the media law on the Kuwaiti media institutions in various fields and their degree, according to the sex variable, Table (7) shows that:

Table (7): shows results of (Independent Sample and T. Test) which were used to detect differences in the effects of the media law on the Kuwaiti media institutions in various fields and their degree according to the (sex) variable.

\begin{tabular}{|l|l|l|l|l|l|l|}
\hline Variable & Category & No. & Mean & Std. Deviations & T. Value & Significance level \\
\hline \multirow{2}{*}{ Sex } & Male & 183 & 2.13 & 0.55 & \multirow{2}{*}{0.90} & \multirow{2}{*}{.3700} \\
\cline { 2 - 5 } & Female & 38 & 2.04 & 0.64 & & \\
\hline
\end{tabular}

Table (7) shows the following:

-There is no significant statistical relationship at $(\alpha \leq 0.05)$ in the consequences of the media law in the various fields and their degree according to the sex variable. The value of " $\mathrm{T}$ " did not reach the significance level of (0.05).

Hypothesis Two: There are significant statistical differences at $\alpha=.05$ between sex and the impact of the new electronic media law positively on the State of Kuwait in various fields.

In order to test this hypothesis, means and standard deviations of the impact of the new electronic media law positively on the State of Kuwait in various fields according to the sex variable. The Independent Samples and T. Test were used to detect the differences in the impact of the new electronic media law positively on the State of Kuwait in various fields according to the sex variable.

Table (8): shows results of (Independent - Sample T. Test) to detect the effect of the new electronic media law positively on the State of Kuwait in various fields according to the sex variable.

\begin{tabular}{|l|l|l|l|l|l|l|}
\hline Variable & Category & No. & Mean & Std. Deviations & T. Value & Significance level \\
\hline \multirow{2}{*}{ Sex } & Male & 183 & 3.78 & 0.95 & \multirow{2}{*}{-1.307} & \multirow{2}{*}{0.193} \\
\cline { 2 - 6 } & Female & 38 & 4.00 & 0.95 & & \\
\hline
\end{tabular}

Table (8) above shows the following: 
- There was no significant statistical relationship at $(\alpha \leq 0.05)$ in the impact of the new electronic media law positively on the State of Kuwait in various fields according to the sex variable; the value of "T" did not reach the significance level of (0.05).

Hypothesis Three: There are significant statistical differences at $\alpha=.05$ between sex and the articles of the new media law

To test this hypothesis, means and standard deviations of the new media law articles were calculated according to sex. The independent Sample and T. Test were used to detect differences in the new media law according to the sex variable.

Table (9): shows independent (Sample T. Test) results for the detection of the new media law according to the sex variable

\begin{tabular}{|l|l|l|l|l|l|l|}
\hline Variable & Category & No. & Mean & Std. Deviations & T. Value & Significance level \\
\hline \multirow{2}{*}{ Sex } & Male & 183 & 3.67 & 183 & \multirow{2}{*}{-1.874} & \multirow{2}{*}{0.062} \\
\cline { 2 - 5 } & Female & 38 & 3.86 & 38 & & \\
\hline
\end{tabular}

Table (9) above shows the following:

- There is no significant statistical relationship at $(\alpha \leq 0.05)$ in the new media law articles according to the sex variable. The values of " $t$ " did not reach the significance level of (0.05)

Hypothesis Four: There are significant statistical differences at $\alpha=.05$ between age and the impact of the new media law on the Kuwaiti press institutions in various fields.

To test this hypothesis, means and standard deviation for the consequences of the media law on the Kuwaiti press institutions in various fields according to (age) Variable. The ANOVA test was also used to detect the differences in the consequences of the media law on the Kuwaiti press institutions in various fields according to the (age).

Table (10): shows results of ANOVA Analysis used to detect differences in the impact of new Media Law on Kuwaiti Press institutions in various fields and their Degree according to (Age) variable

\begin{tabular}{|l|l|l|l|l|l|l|}
\hline Variable & Category & No & Means & $\begin{array}{l}\text { Std. } \\
\text { Deviations }\end{array}$ & $\begin{array}{l}\text { F. } \\
\text { Value }\end{array}$ & $\begin{array}{l}\text { Significance } \\
\text { level }\end{array}$ \\
\hline \multirow{4}{*}{ Age } & 25years \& under & 13 & 1.85 & 0.469 & & \\
\cline { 2 - 5 } & $26-30$ years & 37 & 2.10 & 0.594 & & \multirow{3}{*}{0.531} \\
\cline { 2 - 5 } & $31-35$ years & 70 & 2.05 & 0.552 & \\
\cline { 2 - 5 } & $36-40$ years & 36 & 2.12 & 0.510 & & \\
\cline { 2 - 5 } & 41 years \& above & 71 & 2.23 & 0.580 & & \\
\hline
\end{tabular}

Table (10) above reveals that: 
- There is no significant statistical relationship at (0.05) in the impact of the new Media Law on Kuwaiti press institutions in various fields and their degree according to (age) variable. The values of (f) did not reach the significance level of (0.05).

Hypothesis Five: There are significant statistical differences at $\alpha=.05$ between age and the impact of the new electronic media law positively on the State of Kuwait in various fields.

In order to test this hypothesis, means and standard deviations of the effect of the new electronic media law positively on the State of Kuwait in various fields according to the (age) variable. The ANOVA was also applied to detect the differences in the impact of the new electronic media law positively on the State of Kuwait in various fields, according to the variable (age).

Table (11): shows results of ANOVA to detect differences in the effect of the new electronic media law positively on the State of Kuwait in various fields according to the (age) variable.

\begin{tabular}{|c|c|c|c|c|c|c|}
\hline Variable & Category & No & Means & $\begin{array}{l}\text { Std. } \\
\text { Deviations }\end{array}$ & $\begin{array}{l}\text { F. } \\
\text { Value }\end{array}$ & $\begin{array}{l}\text { Significance } \\
\text { level }\end{array}$ \\
\hline \multirow{5}{*}{ Age } & $\begin{array}{l}\text { 25years } \\
\text { under }\end{array}$ & 13 & 3.69 & 1.023 & \multirow{5}{*}{0.070} & \multirow{5}{*}{0.989} \\
\hline & $26-30$ years & 37 & 3.79 & 0.890 & & \\
\hline & $31-35$ years & 70 & 3.83 & 0.884 & & \\
\hline & $36-40$ years & 36 & 3.85 & 0.834 & & \\
\hline & $\begin{array}{l}41 \text { years \& } \\
\text { above }\end{array}$ & 71 & 3.82 & 1.084 & & \\
\hline
\end{tabular}

Table (11) above shows the following:

There is no significant statistical relationship at (0.05) in the impact of the new Media Law on Kuwaiti press institutions positively in various fields according to (age) variable. The values of (f) did not reach the significance level of (0.05).

Hypothesis six: There are significant statistical differences at $\alpha=.05$ between age and the articles of the new media law.

To test this hypothesis, means and standard deviations of the new electronic media law positively on the State of Kuwait in various fields according to the (age) variable. The ANOVA was also applied to detect the differences in the new electronic media law positively on the State of Kuwait in various fields, according to the (age variable). 
Table (12): shows ANOVA results to detect the differences in the new media law according to the variable (age).

\begin{tabular}{|l|l|l|l|l|l|l|}
\hline Variable & Category & No & Means & $\begin{array}{l}\text { Std. } \\
\text { Deviations }\end{array}$ & F. Value & $\begin{array}{l}\text { Significance } \\
\text { level }\end{array}$ \\
\hline \multirow{5}{*}{ Age } & $\begin{array}{l}\text { 25years \& } \\
\text { under }\end{array}$ & 13 & 3.63 & 0.673 & \\
\cline { 2 - 5 } & $26-30$ years & 37 & 3.66 & 0.701 & \multirow{2}{*}{0.052} & \multirow{2}{*}{0.966} \\
\cline { 2 - 5 } & $31-35$ years & 70 & 3.67 & 0.586 & \\
\cline { 2 - 5 } & $36-40$ years & 36 & 3.73 & 0.713 & \\
\cline { 2 - 5 } & $\begin{array}{l}41 \text { years \& } \\
\text { above }\end{array}$ & 71 & 3.71 & 0.471 & \\
\hline
\end{tabular}

Table (12) above shows the following:

- There is no significant statistical relationship at (0.05) in the new media law according to the (age), variable. The values of (f) did not reach the level of significance level (0.05).

Hypothesis Seven: There are significant statistical differences at $\alpha=.05$ between the educational level and the impact of the media law on Kuwaiti press institutions in various fields and degrees.

To test this hypothesis, means and standard deviations of the impact of new electronic media law positively on the State of Kuwait in various fields according to the (educational level) variable. The ANOVA was also applied to detect the differences in the new electronic media law positively on the State of Kuwait in various fields, according to the (educational level) variable.

Table (13): shows ANOVA results which detected the differences in the new media law according to the (educational level) variable.

\begin{tabular}{|l|l|l|l|l|l|l|}
\hline Variable & Category & No. & Means & $\begin{array}{l}\text { Std. } \\
\text { Deviations }\end{array}$ & $\begin{array}{l}\text { F. } \\
\text { Value }\end{array}$ & $\begin{array}{l}\text { Significance } \\
\text { level }\end{array}$ \\
\hline \multirow{4}{*}{$\begin{array}{l}\text { Educational } \\
\text { Level }\end{array}$} & $\begin{array}{l}\text { Secondary\& } \\
\text { under }\end{array}$ & 25 & 2.27 & 0.60 & & \\
\cline { 2 - 5 } & Diploma & 16 & 1.69 & 0.55 & \multirow{3}{*}{3.849} & \multirow{2}{*}{0.010} \\
\cline { 2 - 5 } & Bachelor & 162 & 2.12 & 0.55 & & \\
\cline { 2 - 5 } & Master/or Ph.D. & 19 & 2.16 & 0.53 & & \\
\hline
\end{tabular}

Table (13) above shows the following:

- There is a significant statistical relationship at (0.05) in the consequences of the new electronic media law on the Kuwaiti press institutions in various fields and their degree according to the variable 
of (educational level) at (0.05). To find the location of differences in women's participation according to the consequences of the electronic media law for the Kuwaiti press institutions in various fields and their degree according to the variable of (educational level).

Table (14): Results of Scheffe Test for post- comparisons on the consequences of the media law for Kuwaiti press institutions in various fields and their degree according to (educational level) variable.

\begin{tabular}{|l|l|l|l|l|l|}
\hline $\begin{array}{l}\text { Educational } \\
\text { Level }\end{array}$ & Means & $\begin{array}{l}\text { Secondary \& } \\
\text { under }\end{array}$ & Diploma & Bachelor & $\begin{array}{l}\text { Master/or } \\
\text { Ph.D. }\end{array}$ \\
\hline $\begin{array}{l}\text { Secondary } \\
\text { \&below }\end{array}$ & 2.27 & -- & $* 0.58$ & 0.15 & 0.11 \\
\hline Diploma & 1.69 & & - & $-* 0.43$ & -0.47 \\
\hline Bachelor & 2.12 & & & -- & -0.043 \\
\hline Master/or Ph.D. & 2.16 & & & & -- \\
\hline
\end{tabular}

Table (14): above shows the areas of differences in the consequences of the new media law of Kuwait media institutions in various fields, and it its degree according to the (educational level) variable were between (secondary and below) and (diploma) for the advantage of (secondary and below). Their mean was (2.27), whereas the mean of (diploma) was (1.69).It was also between (diploma) and (Bachelor) for the advantage of (Bachelor); their mean was (2.12), whereas the Mean of (Diploma) was (1.69). There were no significant statistical differences between the other levels.

Hypothesis Eight: There are significant statistical differences at $\alpha=.05$ between the education level and the positive impact of the new electronic media law on the State of Kuwait in various fields.

In order to test this hypothesis, means and standard deviations of the positive impact of the new electronic media law on the State of Kuwait in various fields according to the (educational level variable). The ANOVA was also applied to detect the differences in the positive impact of the new electronic media law on the State of Kuwait in various fields according to the variable (educational level), 
Table (15): shows results of ANOVA to detect the differences in the positive impact of the new electronic media law on the State of Kuwait in various fields according to the (educational level) variable).

\begin{tabular}{|l|l|l|l|l|l|l|}
\hline Variable & Category & No. & Means & $\begin{array}{l}\text { Std. } \\
\text { Deviations }\end{array}$ & $\begin{array}{l}\text { F. } \\
\text { Value }\end{array}$ & $\begin{array}{l}\text { Significance } \\
\text { level }\end{array}$ \\
\hline \multirow{4}{*}{$\begin{array}{l}\text { Educational } \\
\text { Level }\end{array}$} & $\begin{array}{l}\text { Secondary\& } \\
\text { under }\end{array}$ & 25 & 3.88 & 1.00 & & \\
\cline { 2 - 5 } & Diploma & 16 & 3.92 & 0.91 & \multirow{2}{*}{0.230} & \multirow{2}{*}{0.876} \\
\cline { 2 - 5 } & Bachelor & 162 & 3.80 & 0.94 & & \\
\cline { 2 - 5 } & $\begin{array}{l}\text { Master/or } \\
\text { Ph.D. }\end{array}$ & 19 & 3.68 & 1.05 & & \\
\hline
\end{tabular}

Table (15) above shows that

- There is no significant statistical relationship at $(0.05)$ in the positive impact of the new electronic media law on the State of Kuwait in various fields according to the (educational level) variable. The values of (f) did not reach the significance level (0.05).

Hypothesis Nine: There are significant statistical differences at $\alpha=.05$ between the educational level and the articles of the new electronic media law.

To test this hypothesis, means and standard deviations of the articles of the new law according to the (educational level) variable were calculated. The ANOVA was also applied to detect the differences in the positive impact of the new media law according to the (educational level) variable.

Table (16): shows ANOVA results to detect differences in the new media law articles according to the (educational level) variable.

\begin{tabular}{|l|l|l|l|l|l|l|}
\hline Variable & Category & No. & Means & $\begin{array}{l}\text { Std. } \\
\text { Deviations }\end{array}$ & $\begin{array}{l}\text { F. } \\
\text { Value }\end{array}$ & $\begin{array}{c}\text { Significance } \\
\text { level }\end{array}$ \\
\hline \multirow{4}{*}{$\begin{array}{l}\text { Educational } \\
\text { Level }\end{array}$} & $\begin{array}{l}\text { Secondary\& } \\
\text { under }\end{array}$ & 25 & 3.62 & 0.54 & & \\
\cline { 2 - 5 } & Diploma & 16 & 3.70 & 0.49 & \multirow{2}{*}{0.329} & \multirow{2}{*}{0.804} \\
\cline { 2 - 5 } & Bachelor & 162 & 3.70 & 0.62 & & \\
\cline { 2 - 5 } & $\begin{array}{l}\text { Master/or } \\
\text { Ph.D. }\end{array}$ & 19 & 3.59 & 0.61 & & \\
\hline
\end{tabular}

Table (16): above shows that there is no significant statistical relationship at (0.05) in the new media law articles according to the 
(educational level) variable. The values of (f) did not reach the significance level (0.05).

Hypothesis Ten: There are significant statistical differences at $\alpha=.05$ between the monthly income and the consequences of the new electronic media law on the Kuwaiti press institutions in various fields.

To test this hypothesis, means and standard deviations of the consequences of the new media law on the Kuwaiti media institution in various fields according to the (monthly income variable) were calculated. The ANOVA was also applied to detect the differences in the consequences of media law on the Kuwaiti media institution in various fields according to the (monthly income variable)

Table (17) shows results of ANOVA to detect the differences in the consequences of media law on the Kuwaiti media institution in various fields according to the (monthly income) variable

\begin{tabular}{|l|l|l|l|l|l|l|}
\hline Variable & $\begin{array}{l}\text { Category } \\
\text { KD }\end{array}$ & No. & Means & $\begin{array}{l}\text { Std. } \\
\text { Deviations }\end{array}$ & $\begin{array}{l}\text { F. } \\
\text { Value }\end{array}$ & $\begin{array}{l}\text { Significance } \\
\text { level }\end{array}$ \\
\hline \multirow{4}{*}{$\begin{array}{l}\text { Monthly } \\
\text { Income }\end{array}$} & 1000 \& below & 128 & 2.05 & 128 & & \\
\cline { 2 - 5 } & $1001-2000$ & 48 & 2.22 & 48 & & \\
\cline { 2 - 5 } & $2001-3000$ & 7 & 2.55 & 7 & \multirow{3}{*}{0.62} & \multirow{2}{*}{0.095} \\
\cline { 2 - 5 } & $3001-4000$ & 3 & 2.22 & 3 & \\
\cline { 2 - 5 } & Above 4001 & 2 & 2.00 & 2 & & \\
\hline
\end{tabular}

Table (17) above: shows that there is no significant statistical relationship at (0.05) in the consequences of the electronic media law on the Kuwaiti media institution in various fields according to the (monthly income variable). The values of (f) did not reach the significance level (0.05)

\section{Relationships}

1. What is the relationship between the fourth question: (what is the alternative to the laws of electronic media, publications and publishing) and the monthly income?

To answer this question, the "Chi square" test was used between media honor codes and monthly income, and between an occupational ethics code for all media institutions, and monthly income. The tables below illustrate this 
-The first section: media honor codes

Table (18): shows results of the (chi square) test between media honor codes and monthly income

\begin{tabular}{|c|c|c|c|c|c|c|c|c|}
\hline \multirow{2}{*}{\multicolumn{3}{|c|}{ Answer }} & \multicolumn{6}{|c|}{ Monthly income } \\
\hline & & & \multirow{2}{*}{$\begin{array}{l}\begin{array}{l}\text { D } 1000 \\
\text { and } \\
\text { below }\end{array} \\
79 \\
\end{array}$} & \multirow{2}{*}{$\begin{array}{l}-1001 \\
2000 \\
29\end{array}$} & \multirow{2}{*}{$\begin{array}{l}-2001 \\
3000 \\
4\end{array}$} & \multirow{2}{*}{$\begin{array}{l}-3001 \\
4000 \\
1\end{array}$} & \multirow{2}{*}{$\begin{array}{l}\begin{array}{l}\text { 4001\& } \\
\text { more }\end{array} \\
0\end{array}$} & \multirow{2}{*}{$\begin{array}{l}\text { Total } \\
113\end{array}$} \\
\hline \multirow{6}{*}{$\begin{array}{l}\text { Media } \\
\text { honor } \\
\text { codes }\end{array}$} & \multirow[b]{2}{*}{ Yes } & No & & & & & & \\
\hline & & $\begin{array}{l}\text { Percentage } \\
\%\end{array}$ & $66.9 \%$ & $61.7 \%$ & $57.1 \%$ & $33.3 \%$ & $0.0 \%$ & $63.8 \%$ \\
\hline & \multirow[b]{2}{*}{ No } & No & 39 & 18 & 3 & 2 & 2 & 64 \\
\hline & & $\begin{array}{l}\text { Percentage } \\
\%\end{array}$ & $33.1 \%$ & $\mathbf{3 8 . 3} \%$ & $42.9 \%$ & $66.7 \%$ & $100.0 \%$ & $36.2 \%$ \\
\hline & \multirow[b]{2}{*}{ Total } & No & 118 & 47 & 7 & 3 & 2 & 177 \\
\hline & & $\begin{array}{l}\text { Percentage } \\
\%\end{array}$ & $100.0 \%$ & $100.0 \%$ & $100.0 \%$ & $100.0 \%$ & $100.0 \%$ & $100.0 \%$ \\
\hline \multicolumn{3}{|c|}{ Chi Square } & \multicolumn{6}{|l|}{$5.464^{\mathrm{a}}$} \\
\hline \multicolumn{3}{|c|}{ Significance level } & \multicolumn{6}{|l|}{0.243} \\
\hline
\end{tabular}

Table (18) shows that the value of the significance level (0.243) is greater than 0.05 , indicating that there is no relationship between the media honor codes and the monthly income

- Section II: The code of occupational ethics for all media institutions

Table (19): Shows results of the "Chi square" test between occupational ethics code for all media institutions and monthly income

\begin{tabular}{|c|c|c|c|c|c|c|c|c|}
\hline \multirow{2}{*}{\multicolumn{3}{|c|}{ Answer }} & \multicolumn{6}{|c|}{ Monthly income } \\
\hline & & & \multirow{2}{*}{$\begin{array}{l}\mathrm{D} 1000 \\
\text { and } \\
\text { below } \\
89 \\
\end{array}$} & \multirow{2}{*}{$\begin{array}{l}-1001 \\
2000 \\
35 \\
\end{array}$} & \multirow{2}{*}{$\begin{array}{l}-2001 \\
3000 \\
5 \\
\end{array}$} & \multirow{2}{*}{$\begin{array}{l}-3001 \\
4000 \\
2 \\
\end{array}$} & \multirow{2}{*}{$\begin{array}{l}\begin{array}{l}4001 \& \\
\text { more }\end{array} \\
1 \\
\end{array}$} & \multirow{2}{*}{$\begin{array}{l}\text { Total } \\
132\end{array}$} \\
\hline \multirow{6}{*}{$\begin{array}{l}\text { occupational } \\
\text { ethics code } \\
\text { for all media } \\
\text { institutions }\end{array}$} & \multirow[b]{2}{*}{ Yes } & No. & & & & & & \\
\hline & & $\begin{array}{l}\text { Percentage } \\
\%\end{array}$ & $75.4 \%$ & $76.1 \%$ & $71.4 \%$ & $66.7 \%$ & $100.0 \%$ & $75.4 \%$ \\
\hline & \multirow[b]{2}{*}{ No } & No. & 29 & 11 & 2 & 1 & 0 & 43 \\
\hline & & $\begin{array}{l}\text { Percentage } \\
\%\end{array}$ & $24.6 \%$ & $23.9 \%$ & $28.6 \%$ & $33.3 \%$ & $0.0 \%$ & $24.6 \%$ \\
\hline & \multirow[b]{2}{*}{ Total } & No. & 118 & 46 & 7 & 3 & 1 & 175 \\
\hline & & $\begin{array}{l}\text { Percentage } \\
\%\end{array}$ & $100.0 \%$ & $100.0 \%$ & $100.0 \%$ & $100.0 \%$ & $100.0 \%$ & $100.0 \%$ \\
\hline \multicolumn{3}{|l|}{ Chi Square } & \multicolumn{6}{|l|}{0.521} \\
\hline \multicolumn{3}{|c|}{ Significance level } & \multicolumn{6}{|l|}{0.971} \\
\hline
\end{tabular}

Table (19) shows that the value of the significance level (0.971) is greater than 0.05 , which indicates that there is no relationship between 
a occupational ethics code for all media institutions and monthly income

1. In your opinion, what is the relationship between the fourth question (what is the alternative to the laws of electronic media, publications and publishing) and the educational level?

In order to answer this question, the "Chi square" test was used between media codes of ethics and educational level, and between the occupational ethics code for all media institutions and monthly income. The table below illustrates this.

- First section: media honor codes

Table (20): shows results of the (chi square) test between media honor codes and educational level

\begin{tabular}{|c|c|c|c|c|c|c|c|}
\hline & & & \multicolumn{5}{|c|}{ Educational Level } \\
\hline \multicolumn{3}{|c|}{ Answer } & $\begin{array}{c}\text { Secondary\& } \\
\text { under }\end{array}$ & Diploma & Bachelor & $\begin{array}{l}\text { Master/or } \\
\text { Ph.D. }\end{array}$ & Total \\
\hline \multirow{6}{*}{$\begin{array}{l}\text { Media honor } \\
\text { codes }\end{array}$} & \multirow{2}{*}{ Yes } & No. & 13 & 4 & 88 & 11 & 116 \\
\hline & & Percentage \% & $59.1 \%$ & $30.8 \%$ & $57.9 \%$ & $61.1 \%$ & $56.6 \%$ \\
\hline & \multirow{2}{*}{ No } & No. & 9 & 9 & 64 & 7 & 89 \\
\hline & & Percentage $\%$ & $40.9 \%$ & $69.2 \%$ & $42.1 \%$ & $38.9 \%$ & $43.4 \%$ \\
\hline & \multirow{2}{*}{ Total } & No. & 22 & 13 & 152 & 18 & 205 \\
\hline & & Percentage $\%$ & $100.0 \%$ & $100.0 \%$ & $100.0 \%$ & $100.0 \%$ & $100.0 \%$ \\
\hline \multicolumn{3}{|c|}{ Chi Square } & \multicolumn{5}{|c|}{3.839} \\
\hline \multicolumn{3}{|c|}{ Significance level } & \multicolumn{5}{|c|}{.2790} \\
\hline
\end{tabular}

Table (20) shows that the value of statistical significance (0.279) is greater than 0.05 , indicating that there is no relationship between media honor codes and educational level.

Section two: A code of occupational ethics for all media institutions

Table (21: shows results of the (Chi square) test between media honor codes and educational level.

\begin{tabular}{|c|c|c|c|c|c|c|c|}
\hline & & & \multicolumn{5}{|c|}{ Educational Level } \\
\hline \multicolumn{3}{|c|}{ Answer } & $\begin{array}{l}\text { Secondary } \\
\& \text { under }\end{array}$ & Diploma & Bachelor & $\begin{array}{l}\text { Master/or } \\
\text { Ph.D. }\end{array}$ & Total \\
\hline \multirow{6}{*}{$\begin{array}{l}\text { Media } \\
\text { honor } \\
\text { codes }\end{array}$} & \multirow{2}{*}{ Yes } & No. & 13 & 9 & 117 & 12 & 151 \\
\hline & & Percentage \% & $59.1 \%$ & $64.3 \%$ & $77.5 \%$ & $70.6 \%$ & $74.0 \%$ \\
\hline & \multirow{2}{*}{ No } & No. & 9 & 5 & 34 & 5 & 53 \\
\hline & & Percentage \% & $40.9 \%$ & $35.7 \%$ & $22.5 \%$ & $29.4 \%$ & $26.0 \%$ \\
\hline & \multirow{2}{*}{ Total } & No. & 22 & 14 & 151 & 17 & 204 \\
\hline & & Percentage $\%$ & $100.0 \%$ & $100.0 \%$ & $100.0 \%$ & $100.0 \%$ & $100.0 \%$ \\
\hline \multicolumn{3}{|c|}{ Chi Square } & \multicolumn{5}{|c|}{$4.286^{\mathrm{a}}$} \\
\hline \multicolumn{3}{|c|}{ Significance level } & \multicolumn{5}{|c|}{.2320} \\
\hline
\end{tabular}

Table (21) shows that the value of the significance level (0.320) is greater than 0.05 , indicating that there is no relationship between a occupational ethics code for all media institutions and the educational level 
1. What is the relationship between the items of the first question? To answer this question, Pearson correlation coefficient was extracted between the first question items.

Table (22) below: Shows Pearson correlation coefficient between items of the first question

\begin{tabular}{|c|c|c|c|c|}
\hline & & $\begin{array}{l}\text { Have you seen } \\
\text { the Kuwaiti new } \\
\text { electronic media } \\
\text { law and its } \\
\text { various articles? }\end{array}$ & $\begin{array}{l}\text { Have you seen } \\
\text { the electronic } \\
\text { media laws of } \\
\text { other } \\
\text { countries? }\end{array}$ & $\begin{array}{l}\text { Do you find fundamental } \\
\text { differences between the } \\
\text { electronic media law and } \\
\text { the media laws that you } \\
\text { have seen in other } \\
\text { countries? }\end{array}$ \\
\hline \multirow{2}{*}{$\begin{array}{l}\text { Have you seen the } \\
\text { Kuwaiti new electronic } \\
\text { media law and its various } \\
\text { articles? }\end{array}$} & $\begin{array}{l}\text { Pearson } \\
\text { correlation } \\
\text { coefficient }\end{array}$ & 1 & & \\
\hline & $\begin{array}{l}\text { Significance } \\
\text { level }\end{array}$ & & & \\
\hline \multirow[t]{2}{*}{$\begin{array}{l}\text { Have you seen the } \\
\text { electronic media laws of } \\
\text { other countries? }\end{array}$} & $\begin{array}{l}\text { Pearson } \\
\text { correlation } \\
\text { coefficient } \\
\end{array}$ & $0.356^{* *}$ & 1 & \\
\hline & $\begin{array}{l}\text { Significance } \\
\text { level }\end{array}$ & 0.000 & & \\
\hline \multirow{2}{*}{$\begin{array}{l}\text { Do you find fundamental } \\
\text { differences between the } \\
\text { electronic media law and } \\
\text { the media laws that you } \\
\text { have seen in other } \\
\text { countries? }\end{array}$} & $\begin{array}{l}\text { Pearson } \\
\text { correlation } \\
\text { coefficient }\end{array}$ & $0.181^{*}$ & $0.237^{* *}$ & 1 \\
\hline & $\begin{array}{l}\text { Significance } \\
\text { level }\end{array}$ & 0.026 & 0.003 & \\
\hline
\end{tabular}

Table (22) above: shows that correlation coefficients between the items of the first question ranged from $(0.181-0.356)$, which is a positive relationship statistically significant, which confirms the relationship between the items of the first question.

\section{Recommendations}

Based on the results of the study, the communicators are required to conduct more scientific studies to know the views and directions of those concerned with the laws issued by the legislative authority. This is necessary to prevail for the freedom of journalists working in governmental and private media institutions.

Global openness, globalization of communication and breaking of political and geographic barriers require decision makers to move away from enacting laws that restrict freedom of expression on the one hand, and to focus on the ethics of the occupation to be issued by the media institution itself, and the media men themselves, Making it difficult to control the flow of information, or reduce its negative effects. 


\section{References}

Facebook, (2017), Facebook homepage, June 25, 2017

2. Al-Enezi, B, (2011), "(The Impact of the Publications Law on the Kuwaiti Press, an Applied Study from the Kuwaiti Journalists' Perspective)", Master Thesis, Media College, Middle East University, Amman, Jordan.

3. Al-Shammari, Y,( 2013), "the relationship between media and governments between "soft containment" and independence: field study in the State of Kuwait", Master Thesis, Media College, Middle East University, Amman, Jordan.

4. Kashakesh, K, (2004), Crisis of Press Freedom in the Light of Jordanian Legislation, Yarmouk Researches, Series of Social Sciences, Volume 12, No.2, Irbid, Jordan

5. The State of Kuwait, (1982), Law No. (61), 1982.

6. Jordan, (1976), Law No. (16), 1976.

7. Makawi, E, Al Sayyed, L, (1998), Contemporary Communication Theories, ed. 1, Cairo, the Egyptian Lebanese House

8. Al Abdullah, M, (2010), Theories of Communication, Beirut, Dar al-Nahda al-Arabiya

9. Saleh,S, (2005), Communication Revolution and Freedom of Information, Al Falah Library for Publishing and Distribution.

10. Rashti, J, (1975), Scientific Foundations of the Media Theories, Dar Al-Fikr Al-Arabi, Cairo, p. 299.

11. Al Quteifan, L,( 2013), "The Role of the law to guarantee the right of access to information in media coverage in Jordan, field study from the perspective of Jordanian journalists", Master thesis, Middle East University, Amman, Jordan.

12. Duffy, M. J. (2014). Arab media regulations: Identifying restraints on freedom of the press in the laws of six Arabian Peninsula countries. Berkeley J. Middle E. \& Islamic L., 6, 1.

13. Hafez, K. (2008). The Role of Media in the Arab World's Transformation Process. Inc.-P. Hanelt, \& A. Möller (Eds.), Bound to Cooperate: Europe and the Middle East II (pp.

321-329) .( Gütersloh: Bertelsmann.14

15. Weinberg, J. (2008). Bound and Gagged: Silent Censorship in the Arab Press. Harvard International Review, 30(1), 12

16. Al Ajmi, F. (2011). The new press law: Kuwaiti journalists and newspapers owners' knowledge and attitude. Arkansas State University

17. Siebert. F., Peterson, T. \&Schramm, W.(1956).Four theories of the Press: The authoritarian, Liberation, Social responsibility, and Soviet communist concepts of what the press should be and do. Urbana: University of Illinois

18. Picard, R.,(1985), The Press and the decline of democracy: The democratic socialist response in public policy. Westport, CT: Greenwood

19. Schramm W.(1960), The Gatekeeper: A Memorandum, in W. Schramm (ed.) Mass Communication, 1960 p.175

20. Lewin, K.(1951).Field Theory in Social Science. N.Y, Harper 